\title{
Complex Regional Pain Syndrome Following Snakebite: A Putatively Rare Complication of Envenomation and Review of the Literature
}

This article was published in the following Dove Press journal: International Medical Case Reports Journal

\section{Reynaldo P Lazaro (D)}

Neurology and Electromyography Clinic, Oneonta, NY 13820, USA
Correspondence: Reynaldo P Lazaro Neurology and Electromyography Clinic, 4I-45 Dietz Street, Oneonta, NY I3820, USA

Tel + I $607432-827$

$\mathrm{Fax}+|60744|-505 \mid$

Email RPL528@cs.com
Background: Complex regional pain syndrome (CRPS) following snakebite is considered rare. Only four cases have been reported in the world literature. The present case is the first in the United States. We felt the need to report this case to bring attention to health-care providers that CRPS is probably an under-recognized complication of snakebite.

Case Presentation: A 44-year-old right-handed man developed signs and symptoms of complex regional pain syndrome (CRPS) in the left upper extremity following a bite by a cat-eyed snake (genus Leptodeira), a slightly venomous snake that belongs to the Colubridae (colubrids) family. The man did not develop muscle weakness or hematologic complications at that time. However, in subsequent years, he developed sporadic jerking of the upper extremities without alteration in consciousness or electroencephalographic abnormalities. These movements tended to occur during emotional tension and exacerbation of pain, and decreased in frequency when the subject was distracted. This is the fifth case of snakebite-induced CRPS described in the world literature (Nepal, Turkey, Korea, and Norway), the first reported in the United States, and the first induced by a slightly venomous snake.

Conclusion: With closer attention to the presence of indicators of sympathetic nerve dysfunction in association with allodynia, it is probable that cases of persistent pain following snakebite might have been instances of CRPS.

Keywords: complex regional pain, snakebite, envenomation, myoclonus, movement disorder, neurotoxin, hemotoxin

\section{Introduction}

The literature on complex regional pain syndrome (CRPS), an enigmatic medical condition, is voluminous. Its pathophysiology, however, hitherto remains abstruse. It is a syndrome with no specific pathognomonic signs or symptoms. Allodynia, a painful condition that can be evoked even by a light touch on the skin, is a prominent symptom in the affected limb, and is associated with indicators of sympathetic nerve dysfunction - cool and warm sensation, reddish or pale discoloration and swelling (with or without excessive sweating). Movement disorders and trophic changes in the skin, joints, and bones are known to occur at various times or as the condition progresses. ${ }^{1-4}$ The clinical course is variable, can evolve acutely or subacutely, and in some cases, linger or fluctuate chronically. ${ }^{5}$ Trauma is a frequent inciting event, and the diagnosis is established clinically. There are no laboratory procedures specific for this condition, though thermal imaging can document temperature changes resulting 
from sympathetic nerve overactivity, and a three-phase bone scan can demonstrate the altered bone metabolism and blood flow in CRPS.

Here, a case of CRPS that developed in a 44-year-old man following a snakebite is reported. Worldwide, four cases have been reported to date. ${ }^{6-9}$ The present report is the first in the United States, though the rarity seems more apparent than real considering that some snakebite victims continue to complain of pain accompanied by vasomotor symptoms years after envenomation.

\section{Case Presentation}

This 44-year-old right-handed, previously healthy man was filing and carrying wooden crates of food items inside a warehouse in upstate New York when he was bitten by a cat-eyed snake (Leptodeira, of undetermined species). The crates originated from southern Texas. There were two puncture wounds in the distal third of the anterior aspect of the left forearm (Figure 1). The pain was agonizing and his left hand was quite stiff, erythematous, and swollen. He managed to take a photograph of the snake (Figure 2) with his cell phone. The snake eventually escaped. Within a few hours, the skin over the bite site burst, followed by fever, chills, nausea, and light-headedness. A few hours later, he went to a local clinic where he underwent asepsis and antisepsis over the bite site along with the local application of steroid medication and analgesic. Antivenom was not given. He never developed respiratory difficulties, renal failure, oculo-visual symptoms, limb paralysis, bulbar muscle weakness, or hemorrhagic diathesis.

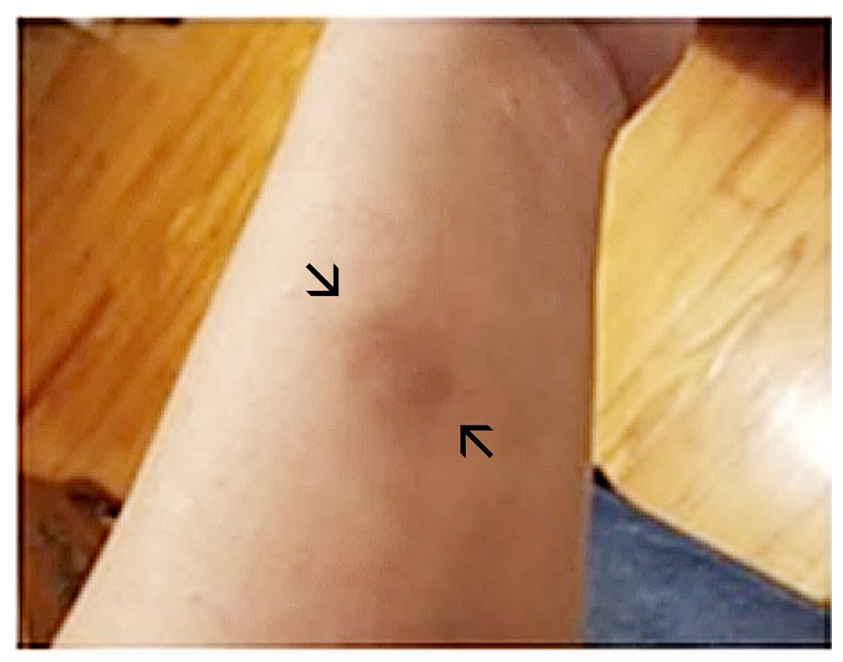

Figure I Two puncture wounds (arrows) on the anterior aspect of the left forearm.

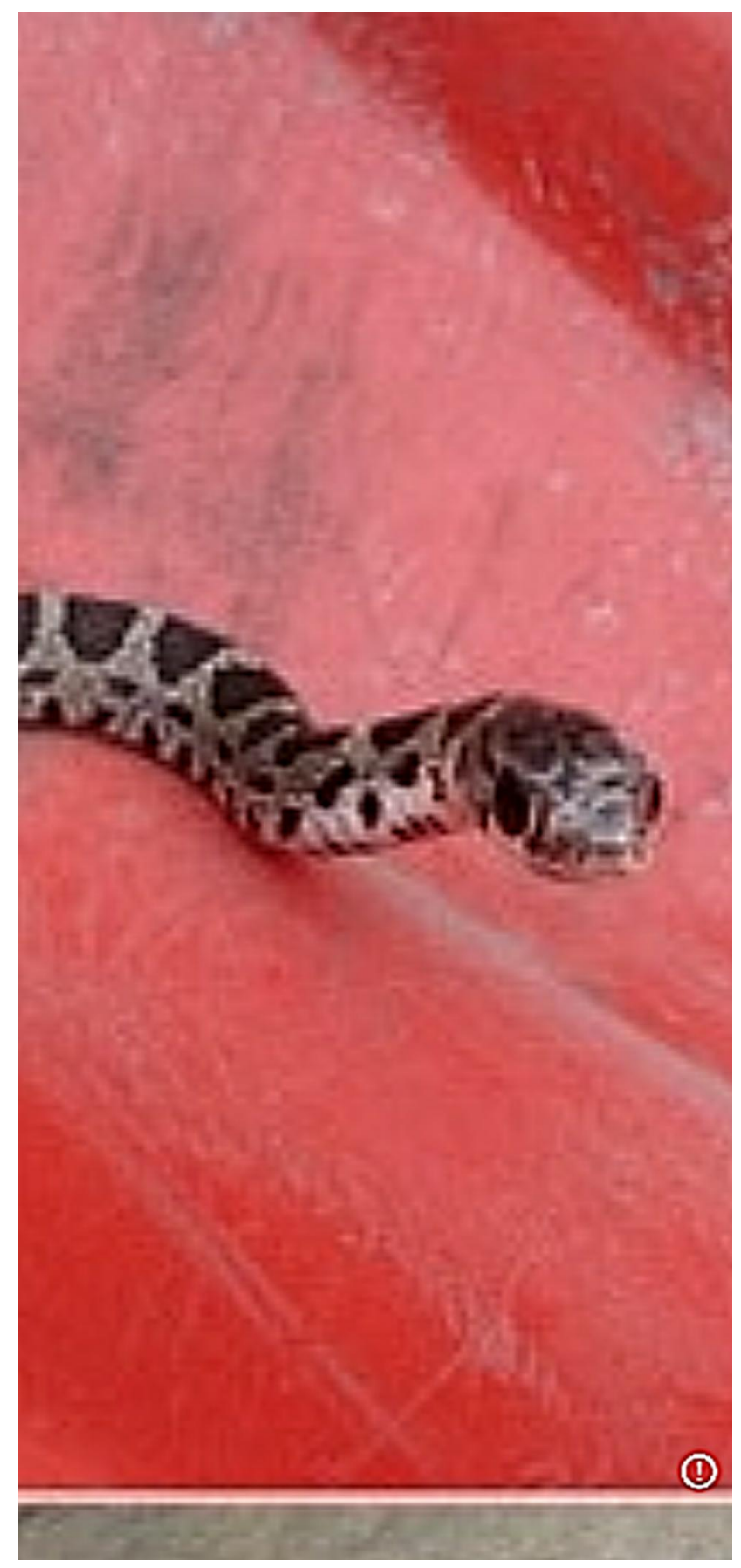

Figure 2 Cat-eyed snake with large eyes and dark brown blotches throughout the length of the snake's body, characteristic of species of Leptodeira.

In subsequent months after the wound began to heal, a constellation of signs and symptoms consistent with CRPS-hyperalgesia, swelling, alternating cool and warm sensation, dermal changes (discoloration and smoothening of the skin), and mild flexion contractures of the fingers - evolved gradually (Figure 3). Sporadic, arrhythmic, brief and sudden involuntary movements that occurred during emotional tension and anxiety, 


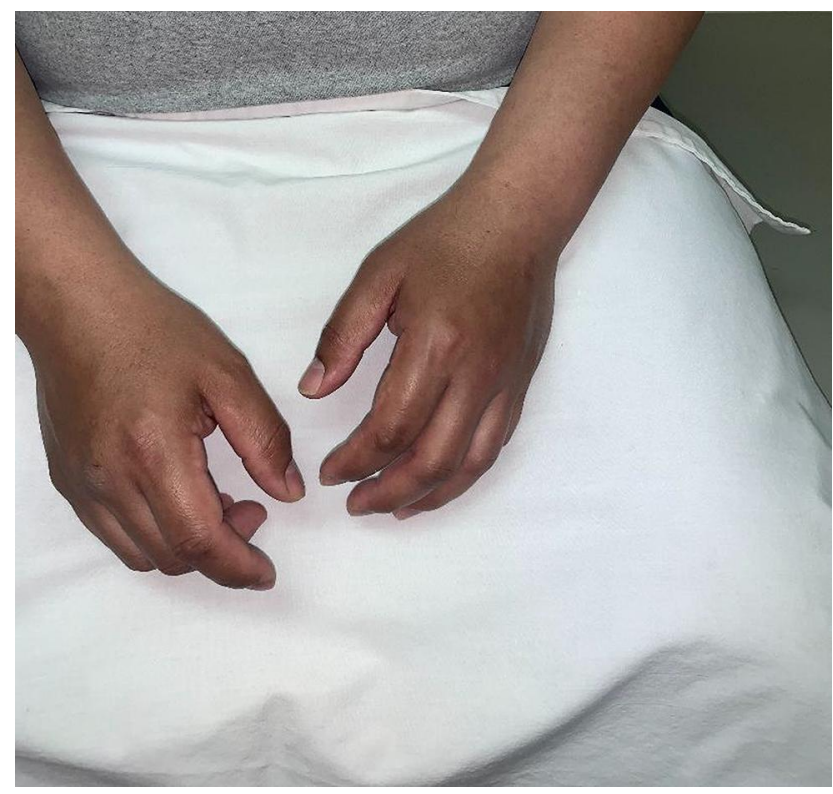

Figure 3 Photograph of the hands two years after snakebite. The skin on the left is glossy with mild disuse atrophy of the thumb. Flexion postures of the fingers are evident but they are not contracted.

and subsided when distracted, developed in the upper extremities and trunk.

Apart from the clinical signs of CRPS, the general physical and neurologic examination showed no findings that would correlate with the abnormalities in the left upper extremity.

Normal laboratory test procedures included a hemogram, metabolic profiles, a rheumatological screening, a conventional electroencephalogram (performed simultaneously with involuntary movements), a nerve conduction examination, and an electromyogram. Magnetic resonance imaging of the cervical spine showed mild bulging discs and mild foraminal stenosis at the C6-7 level. The bone scan, which showed normal three-phase activity, was not deemed necessary to repeat, in view of clear signs of CRPS as the condition progressed.

Despite the intake of gabapentin, pregabalin, valproic acid, primidone and duloxetine, the pain and myoclonic movements did not subside significantly. Concerns about addiction and drug dependence precluded the use of narcotic analgesics and benzodiazepines. Physical therapy was also not helpful. Various bureaucratic issues prevented the institution of sympathetic nerve blocks and various alternative therapeutic modalities.

\section{Discussion}

Snakes are found on every continent except Antarctica. Most are nonvenomous or have the venom of low toxicity.
Highly venomous snakes have modified saliva that consists mainly of proteins, toxic enzymes and polypeptides that are neurotoxic, cytotoxic, or hemotoxic. Venomous snakes are classified into four taxonomic families: Elapidae (elapids), Viperidae (viperids), Atractaspididae (atractaspidids), and Colubridae (colubrids). Elapids include cobras, kraits, mambas, Australian copperheads, sea snakes, and coral snakes. Their venom is typically neurotoxic, attacking the presynaptic and postsynaptic region of the neuromuscular junction. This results in the disruption of acetylcholine transmission, which leads to paralysis and respiratory failure. Viperids include vipers, rattlesnakes, copperheads/cottonmouths, and bushmasters. Their venom is typically either hemotoxic (affecting clotting factors and lysis of the phospholipid membrane of red blood cells, resulting in coagulopathy), or cytotoxic (affecting cell membranes of the tissues at the bite site, leading to necrosis). Atractaspidids (eg burrowing asps, mole vipers, stiletto snakes) and colubrids (mostly harmless, though boomslang and others have caused fatalities) have hemotoxic venom. ${ }^{10-20}$ Worldwide, approximately 5.5 million bites, 1.8 million envenomations, and 94,000 deaths occur each year, with a higher incidence in Africa, Asia, and Latin America. However, the precise incidence is unknown, owing to a lack of methodical reporting in those continents/ regions. Still, it is a major and global health issue. ${ }^{21,22}$

The snake involved in the present case had the distinctive appearance of a cat-eyed snake (genus Leptodeira), a species of medium-sized, slightly venomous snake belonging to the genus Colubridae (Figure 2), found in southern Texas and Central America. It has smooth scales, dark brown blotches on the body, and a dark brown spot beside each eye. Adults have an average length of $45-60 \mathrm{~cm}$. The head is distinctly wider than the neck and it has large eyes with vertical pupils resembling those of the cat. ${ }^{23}$ The snake has been known to stow away in crates containing food items. However, the possibility that the snake was a coluber or masticophis, which is also common in the northern part of Central America, could not be ruled out completely.

Long-term sequelae of snakebites are debilitating and can persist for weeks or years. Disabilities are the result of the effects of amputation, contractures of the joints, chronic ulceration and tissue necrosis, renal failure, endocrine dysfunction (particularly hypopituitarism), various neuropsychologic disorders, and persistent pain associated with various sensory symptoms and dermal changes in the affected extremity. ${ }^{24,25}$ It is reasonable to speculate that some of 
those victims who suffered from chronic pain following the bite might have been instances of CRPS. Although only four cases of CRPS following a snake bite have been reported in the literature (Table 1), the actual number of cases might be higher with closer inspection for signs and symptoms of sympathetic nerve overactivity and allodynia. The involuntary movements that developed in our patients, which were not observed in the previous four cases, were consistent with myoclonus, a movement disorder that occurs in some patients with CRPS but is different from other forms of myoclonus that originate in the central nervous system and spinal cord. ${ }^{26}$ In our patient, the myoclonus was probably functional or psychogenic but polymyography, ${ }^{27}$ which was not performed, would have been useful to further characterize the condition. In general, myoclonic movements are difficult to manage, and the role of somatic and psychogenic factors in the genesis of this movement disorder only increases its complexity. ${ }^{28}$ Studies have shown that central sensitization at the spinal level induced by tissue or neural injury can alter sensory transmission and sensorimotor processing in the spinal cord leading to loss of voluntary control. ${ }^{2,29,30}$

Of the previous four cases of snakebite-induced CRPS, three were caused by viper bite and one was not identified. Only one received anti-snake venom. Viperids often have cytotoxic venom containing proteolytic enzyme that disrupts the cell membranes of the tissues at the bite site. ${ }^{10,12,14}$ The bite is extremely painful and, as in most

Table I Summary of Published Reports of CRPS Induced by Snake Bite, Listed Chronologically

\begin{tabular}{|l|l|l|l|}
\hline $\begin{array}{l}\text { Authors } \\
\text { Country/ } \\
\text { Date }\end{array}$ & $\begin{array}{l}\text { Patient } \\
\text { Age/ } \\
\text { Gender }\end{array}$ & $\begin{array}{l}\text { Identity of Snake/ Site } \\
\text { of Bite }\end{array}$ & $\begin{array}{l}\text { Type of } \\
\text { CRPS }\end{array}$ \\
\hline $\begin{array}{l}\text { Bhattarai et al } \\
\text { Nepal/2008 }\end{array}$ & $55 / F$ & $\begin{array}{l}\text { Mountain Pit Viper } \\
\text { (Oviphus monticola)/ left } \\
\text { hand }\end{array}$ & I \\
\hline $\begin{array}{l}\text { Ergan et al } \\
\text { Turkey/20I2 }\end{array}$ & $66 / \mathrm{M}$ & $\begin{array}{l}\text { Unidentified type/ left } \\
\text { hand }\end{array}$ & $\begin{array}{l}\text { Possibly } \\
2\end{array}$ \\
\hline $\begin{array}{l}\text { Seo et al } \\
\text { Korea/20I4 }\end{array}$ & $44 / F$ & $\begin{array}{l}\text { Chinese Viper (Agkistrodon } \\
\text { ussuriensis)/ right ankle }\end{array}$ & I \\
\hline $\begin{array}{l}\text { Kleggetveit } \\
\text { et al }{ }^{9} \text { Norway/ } \\
2015\end{array}$ & $22 / F$ & $\begin{array}{l}\text { European Viper (Vipera } \\
\text { berus)/ right arm }\end{array}$ & I \\
\hline $\begin{array}{l}\text { Lazaro (present } \\
\text { case United } \\
\text { States/2020) }\end{array}$ & $44 / M$ & $\begin{array}{l}\text { Cat-eyed Snake } \\
\text { (Leptodeira of } \\
\text { undetermined species)/ } \\
\text { left forearm }\end{array}$ & I \\
\hline
\end{tabular}

cases of post-traumatic CRPS, the site may serve as a "nidus" for the induction of CRPS.

Reports of CRPS induced by neurotoxins of elapids are not available at this time but the destruction of the pre- and postsynaptic segments of the synapses and the neuromuscular junction by the toxin may be relevant to the pathophysiology of CRPS. By the same token, the effect of the venom of the Leptodeira genus, which contain metalloproteinases and phospholipase A2, ${ }^{31}$ on vascular permeability locally but without affecting the neural synaptic terminals, may have a facilitatory influence on the induction of CRPS in both the present (colubrid bite) and previous (viperid bite) cases. Systematic retrospective and/or prospective studies on the true incidence of CRPS induced by envenomation, with emphasis on the correlation between the type of venom and the incidence of CRPS including the effect of anti-snake venom therapy, could potentially be useful both therapeutically and prognostically.

\section{Addendum}

A week after our case report was submitted for peer review on August 11, 2020, an article titled, "Complex Regional Pain Developing After a Coral Snake Bite: A Case Report", was published on August 16, 2020 in the journal Cureus-12(8):e9787.doi:10.7759/cureus.9787, authored by EM Cruz Salcedo, A Blanco, and J Reed of the Ocala Regional Medical Center/University of Central Florida College of Medicine. This article, along with the present case, supports our speculation that CRPS following snake bite is an underrecognized condition.

\section{Ethics and Consent Statements}

The patient gave his verbal and written consent to present his case history, including photographs of his forearm and hands (excluding the face), and the snake, to the medical community and scientific journal for publication. St. Peter's (Albany, NY) IRB has determined that this study does not constitute human research and therefore does not require oversight.

\section{Acknowledgments}

Detailed editing by Mr. Michael W. Lazaro and by Scribendi Editing Service in Ontario, Canada was quite invaluable. Special thanks goes to Ms. Alyce Bauer for assorting the clinical materials and laboratory data on the patient.

\section{Disclosure}

The author reports no conflicts of interest in this work. 


\section{References}

1. de Mos M, Sturkenboom M, Hygen FJ. Current understandings on complex regional pain syndrome. Pain Pract. 2009;9(2):86-99. doi:10.1111/j.1533-2500.2009.00262.x

2. Schartzman RJ, Kerrigan J. The movement disorder of reflex sympathetic dystrophy. Neurology. 1990;40(1):457-461. doi:10.1212/ wnl.40.1.57

3. van Hilten JJ, van de Beek WJT, Vein AA, van Dijk JG, Middelkoop HA. Clinical aspects of multifocal or generalized tonic dystonia in reflex sympathetic dystrophy. Neurology. 2001;56 (12):1762-1765. doi:10.1212/WNL.56.12.1762

4. Birklein F, O'Neill D, Schlereth T. Complex regional pain syndrome: an optimistic perspective. Neurology. 2015;84(1):89-96. doi:10.1212/ WNL.0000000000001095

5. Lazaro RP. Complex regional pain syndrome: medical and legal ramifications of clinical variability and experience and perspective of a practicing clinician. J Pain Res. 2016;10:9-14. doi:10.2147/JPR. S119308

6. Bhattarai B, Shrestha BP, Rahman TR, Sharma SK, Tripathi M. Complex regional pain syndrome (CRPS) type-1 following snake bite: a case report. Nepal Med Coll J. 2008;10(4):278-280.

7. Ergan SA, Yoleri O, Yavasi S, Olmez N, Memis A. Complex regional pain syndrome caused by snake bite: a case report. Turk $J$ Phys Med Rehabil. 2012;58(1):69-71. doi:10.4274/tftr.83723

8. Seo YH, Park MR, Yoo SH. Development of complex regional pain syndrome after a snake bite: a case report. Korean J Pain. 2014;27 (1):68-71. doi:10.3344/kjp.2014.27.1.68

9. Kleggetveit IP, Skulberg PK, Jørum E. Complex regional pain syndrome following viper-bite. Scand J Pain. 2016;10(1):15-18. doi:10.1016/j.sjpain.2015.07.005.

10. Costa LG, Giordano G, Aschner M. Snake venoms. In: Daroff RB, Aminoff MJ, editors. Encyclopedia of the Neurological Sciences. 2nd ed. Waltham, MA: Elsevier; 2014:227.

11. Gold BS, Wingert WA. Snake venom poisoning in the United States: a review of therapeutic practice. South Med J. 1994;87(6):579-589. doi:10.1097/00007611-199406000-00001

12. Hodgson WC, Wickramaratna JC. Snake venoms and their toxins: an Australian perspective. Toxicon. 2006;48(7):931-940. doi:10.1016/j. toxicon.2006.07.018

13. Lomonte B, Fernández J, Sanz L, et al. Venomous snakes of Costa Rica: biological and medical implications of their venom proteomic profiles analyzed through the strategy of snake venomics. J Proteomics. 2014;105:323-339. doi:10.1016/j.jprot.2014.02.020

14. Mackessy SP. Biochemistry and pharmacology of colubrid snake venoms. J Toxicol Toxin Rev. 2002;21(1-2):43-83. doi:10.1081/ TXR-120004741

15. O'Shea M. Venomous Snakes of the World. Princeton, NJ: Princeton University Press; 2005.

16. Boyer LV, Seifert SA, Clark RF, et al. Recurrent and persistent coagulopathy following pit viper envenomation. Arch Intern Med. 1999;159(7):706-710. doi:10.1001/archinte.159.7.706
17. Fazelat J, Teperman SH, Touger M. Recurrent hemorrhage after western diamondback rattlesnake envenomation treated with crotalidae polyvalent immune fab (ovine). Clin Toxicol (Phila). 2008;46 (9):823-826. doi:10.1080/15563650701753849

18. Levine M, Ruha A-M, Padilla-Jones A, Gerkin R, Thomas SH. Bleeding following rattlesnake envenomation in patients with preenvenomation use of antiplatelet or anticoagulant medications. Acad Emerg Med. 2014;21(3):301-307. doi:10.1111/acem.12333

19. Natarajan N, Basheer A, Mookkappan S, Periyasamy S. Reversible lower limb deep vein thrombosis following haemotoxic snakebite-a case report. Australas Med J. 2104;7(5):232-235. doi:10.4066/ AMJ.2014.2075

20. Del Brutto OH, Del Brutto VJ. Neurological complications of venomous snake bites: a review. Acta Neurol Scand. 2012;125 (6):363-372. doi:10.1111/j.1600-0404.2011.01593.x

21. Chippaux JP. Snake-bites: appraisal of the global situation. Bull World Health Organ. 1998;76(5):515-524.

22. Kasturirante A, Wickremasinghe AR, de Silva N, et al. The global burden of snakebite: a literature analysis and modeling based on regional estimates of envenoming and deaths. PLoS Med. 2008;5:1591-1604. doi:10.1371/journal.pmed.0050218

23. Barrio-Amoros CL. On the taxonomy of snakes in the genus Leptodeira, with an emphasis on Costa Rican species. Reptiles Amphib. 2019;26(1):1-15.

24. Spano SJ, Vohra R, Macias F. Long-term complications of rattlesnake bites: a telephone survey from Central California. Wilderness Environ Med. 2014;25(2):210-213. doi:10.1016/j.wem.2013.11.004

25. Waiddyanatha S, Silva A, Siribaddana S, Isbister GK. Long-term effects of snake envenoming. Toxins (Basel). 2019;11(4):193. doi:10.3390/toxins 11040193

26. Munts AG, van Rootselaar A-F, van der Meer JN, Koelman JHTM, van Hilten JJ, Tijssen MAJ. Clinical and neurophysiological characterization of myoclonus in complex regional pain syndrome. Mov Disord. 2008;23(4):581-587. doi:10.1002/mds.21910

27. Apartis E. Clinical neurophysiology of psychogenic movement disorders: how to diagnose psychogenic tremor and myoclonus. Neurophysiol Clin. 2014;44(4):417-424. doi:10.1016/j. neucli.2013.08.014

28. Verdugo RJ, Ochoa JL. Abnormal movements in complex regional pain syndrome: assessment of their nature. Muscle Nerve. 2000;23 (2):198-205. doi:10.1002/(sici)1097-4598(200002)23:2<198::aidmus $9>3.0 . c 0 ; 2-4$

29. van Hilten JJ. Movement disorders in complex regional pain syndrome. Pain Med. 2010;11(8):1274-1277. doi:10.1111/j.15264637.2010.00916.x

30. Woolf CJ, Mannion RJ. Neuropathic pain: aetiology, symptoms, mechanisms, and management. Lancet. 1999;353(9168):1959-1964. doi:10.1016/S0140-6736(99)01307-0

31. Torres-Bonilla KA, Panunto PC, Pereira BB, et al. Toxinological characterization of venom from Leptodeira annulata (banded cat-eyed snake; Dipsadidae, Imantodini). Biochimie. 2020;174:171-188. doi:10. 1016/j.biochi.2020.04.006

International Medical Case Reports Journal

Dovepress

\section{Publish your work in this journal}

The International Medical Case Reports Journal is an international, peer-reviewed open-access journal publishing original case reports from all medical specialties. Previously unpublished medical posters are also accepted relating to any area of clinical or preclinical science. Submissions should not normally exceed 2,000 words or 4

published pages including figures, diagrams and references. The manuscript management system is completely online and includes a very quick and fair peer-review system, which is all easy to use. Visit http://www.dovepress.com/testimonials.php to read real quotes from published authors. 